\title{
GUCA2A wt Allele
}

National Cancer Institute

\section{Source}

National Cancer Institute. GUCA2A wt Allele. NCI Thesaurus. Code C126516.

Human GUCA2A wild-type allele is located within 1p35-p34 and is approximately $2 \mathrm{~kb}$ in length. This allele, which encodes guanylin protein, is involved in the regulation of intestinal guanylate cyclase activity. 